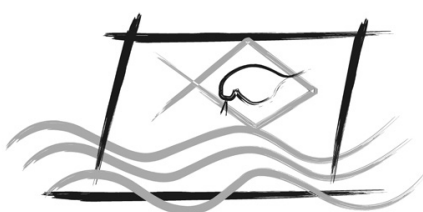

ECOTOX - BRASIL

\title{
Toxicity of quaternary mixtures of phenolic compounds and formulated glyphosate to microbial community of river water
}

\author{
Nweke, C.O. ${ }^{1 *} ;$ Ike, C.C. ${ }^{2} \&$ Ibegbulem, C.O. ${ }^{3}$ \\ 1 Department of Microbiology, Federal University of Technology, P.M.B.1526, Owerri, Nigeria. \\ 2 Department of Microbiology, Rhema University, P. M. B. 7021, Aba, Nigeria. \\ 3 Department of Biochemistry, Federal University of Technology, P.M.B. 1526, Owerri, Nigeria.
}

(Received February 02, 2016; Accept September 20, 2016)

\begin{abstract}
The toxicity of mixtures of formulated glyphosate, phenol, 4-chlorophenol and 2,4-dichlorophenol to river water microbial community was investigated using non specific dehydrogenase activity as endpoint. The microbial community was exposed to individual toxicant and quaternary mixture ratios at concentrations ranging from $50 \mathrm{mg} \mathrm{L}^{-1}$ to $3000 \mathrm{mg} \mathrm{L}^{-1}$ over $24 \mathrm{~h}$. The ecological doses $\left(E C_{50}\right)$ as estimated from logistic or hormesis dose-effect models were $1317.946 \pm 51.460 \mathrm{mg} \mathrm{L}^{-1}, 1046.414$ $\pm 65.534 \mathrm{mg} \mathrm{L}^{-1}, 85.080 \pm 4.468 \mathrm{mg} \mathrm{L}^{-1}$ and $60.897 \pm 5.199 \mathrm{mg} \mathrm{L}^{-1}$ for formulated glyphosate, phenol, 4-chlorophenol and 2,4-dichlorophenol respectively. The toxicity and interaction of the mixtures were evaluated using concentration addition and toxic index models. The model deviation ratios (MDR) ranged from $0.553 \pm 0.024$ to $1.096 \pm 0.021$ while the toxic index (TI) varied between $0.912 \pm 0.017$ and $1.810 \pm 0.078$. However, the MDR and TI for all mixtures lie between 0.5 and 2.0. Thus, the joint action of the mixtures were considered additive.
\end{abstract}

Keywords: Dehydrogenase activity, concentration addition model, herbicide, $E C_{50}$.

\section{INTRODUCTION}

Glyphosate [N-(phosphonomethyl)glycine] is a postemergence herbicide that inhibit the photosynthesis process of terrestrial and aquatic plants. It is the active ingredient of Roundup ${ }^{\circledR}$, a widely used herbicide containing polyoxyethylene amime (POEA), a surfactant that enhances herbicidal action and to which toxicity of Roundup ${ }^{\circledR}$ is attributed (Tsui, 2003). In order to improve pesticide efficacy, glyphosate is usually applied as a mixture with other herbicides. Among the herbicides used in combination with glyphosate are phenoxy herbicides including 2,4-dichlorophenoxyacetic acid (2,4-D) (Lym, 2000; Sharma \& Singh, 2001).

In soils and aquatic environments, the amine salts and esters of 2,4-D are degraded faster than glyphosate. The halflife of 2,4-D ranges from 1 to 14 days while the half life of glyphosate varied between 2 and 197 days (Giesey et al., 2000; US EPA, 2005). In the environment, 2,4-D is initially degraded to 2,4-dichlorophenol (2,4-DCP) (Daugherty and
Karel, 1994) which can be degraded to 3,5-dichlorocatechol, 4-chlorophenol (4-CP) and phenol (Kohring et al., 1989; Zhang \& Wiegel 1990; Fukumori \& Hausinger, 1993) depending on the environmental conditions and the microorganisms involved. Therefore, these phenolic intermediates normally co-contaminate environmental media following application of glyphosate and 2,4-D mixture. Thus, it is imperative to evaluate the interactive toxicities of glyphosate and the phenolic intermediates of 2,4-D biodegradation

Although, as individual chemicals, toxicity of glyphosate and 2,4-D or its intermediates to microorganisms have been widely reported, not much work have been done on the toxicity of glyphosate and phenolic compounds as mixtures. Recently, Nweke et al. $(2014,2015)$ evaluated the joint action of binary mixtures of formulated glyphosate and phenolic intermediates (2,4-DCP, 4-CP and phenol) of 2,4-D biodegradation against dehydrogenase activity in pure culture of Rhizobium species isolated from the root nodule of a leguminous plant. The studies suggested additive interactions of formulated 
glyphosate with the phenolic compounds. There is need to extend such investigation to microbial communities of natural ecosystems. In natural environments, organisms are not usually subjected to toxicity of single pollutant but to mixture toxicity of a variety of pollutants. Combinations of pollutants even at no observed effect concentrations (NOEC) can produce significant toxic effects (Faust et al., 2003). Given the fact that microbes are vital for the efficient functioning of any ecosystem and are early warning indicator of ecosystem stress (Griffiths, 1983; Odum, 1985), it is important to investigate the mixture toxicity of pollutants on natural environmental microflora.

In this regard, toxicity assessment based on inhibition of dehydrogenase activity in natural microbial community using 2-(p-iodophenyl-3-(p-nitrophenyl)-5-phenytetrazolium chloride (INT) is widely used. Dehydrogenases are oxidoreductase enzymes that participate in respiration in microbial cells. Redox indicators serve as artificial electron acceptors in dehydrogenase activity assays to measure intracellular flux of electrons. INT is among the widely used tetrazolium salt in dehydrogenase activity assay. In this process, INT compete with the natural enzymes involved in microbial respiration, acting as electron acceptor and is reduced to red-coloured INT-formazan by a battery of microbial dehydrogenases that catalyze the movement of electrons from substrates to electron acceptors in respiratory chain (Trevors, 1984). Dehydrogenase activity is used as a measure of cell viability because dehydrogenase enzymes are intracellular and rapidly degraded following cell death (Rossel et al., 1997). Thus, INT could be used to assess ecotoxicological impacts of chemicals in an environment. INT and other tetrazolium salts have been used to measure dehydrogenase activity in many environments, including pure culture of microorganisms (Bitton et al., 1986; Baarschers et al., 1988), activated sludge (Kim et al., 1994; Caravalli et al., 2004), Biofilters (Fonseca et al., 2001), soil (Moreno et al., 2002) and aquatic systems (Aonofriesei, 2007; Schneider \& Topalova, 2009).

In the present study, inhibition of INT-dehydrogenase activity was used to evaluate the toxicity of 2,4-DCP, 4-CP, phenol and formulaed glyphosate as well as their quaternary mixtures to microbial community of river water. Fixed ratio rays were employed to study the joint action of the mixtures at various concentrations and the effects of the mixtures on dehydrogenase enzyme activity in the microbial community was evaluated using concentration addition (CA) and toxic index (TI) models.

\section{MATERIALS AND METHODS}

\section{Riverwater sample}

River water was collected from Otamiri River at Ihiagwa, Imo State, south-eastern Nigeria. Water samples were collected midstream along the course of the river at three spots $\left(5^{\circ} 24.25^{\prime} 0.32^{\prime \prime} \mathrm{N}, 7^{\circ} 0.36^{\prime} 0.036^{\prime \prime} \mathrm{E} ; 5^{\circ} 24.28^{\prime} 0.55^{\prime \prime} \mathrm{N}, 7^{\circ} 0.38^{\prime} 0.36^{\prime \prime} \mathrm{E}\right.$ and $\left.5^{\circ} 23.55^{\prime} 0.20^{\prime \prime} \mathrm{N}, 6^{\circ} 59.46^{\prime} 0.39^{\prime \prime} \mathrm{E}\right)$ from a depth of $30 \mathrm{~cm}$ and pooled in 1-litre sterile plastic bottle. The pooled sample was stored in a cooler and taken to laboratory. The bacterial load of the sample was determined on nutrient agar plates within $6 \mathrm{~h}$ of collection using standard microbiological procedure. Within the period, the water sample was used as inoculum for the toxicity assay. The bacterial load of the water sample was estimated at $1.32 \times 10^{10} \mathrm{CFU} / \mathrm{ml}$.

\section{Quaternary mixture ratios}

The quaternary mixtures of glyphosate (as active ingredient in formulated glyphosate pesticide, Roundup), phenol, 4-CP and 2,4-DCP were studied along fixed ratio rays. The bioassays were aimed at determining the toxicity of each of the three phenolic compounds mentioned above in quaternary mixtures with glyphosate as a function of weight to weight ratios as shown in Table 1 .

Table 1- Quaternary mixture ratios of glyphosate, phenol, 4-CP and 2.4DCP

\begin{tabular}{lc}
\hline Mixture & Mixture ratio (\%) \\
& Glyphosate: Phenol: 4-CP: 2,4-DCP \\
\hline 1 & $10: 10: 40: 40$ \\
2 & $60: 20: 10: 10$ \\
3 & $5: 5: 10: 80$ \\
4 & $80: 10: 5: 5$ \\
5 & $5: 80: 5: 10$ \\
6 & $25: 25: 25: 25$ \\
\hline
\end{tabular}

\section{Dehydrogenase activity assay}

A colorimetric assay with 2-(p-Iodophenyl)-3-(pnitrophenyl)-5-phenyl tetrazolium chloride (INT) as an artificial electron acceptor was applied for the assay of dehydrogenase activity using the method of Nweke et al. (2014) with little modification. The reaction mixture consisted of 2-ml final volumes of phosphate-buffered $(\mathrm{pH} 7)$ nutrient broth supplemented with varying concentrations of 2,4-dichlorophenol, 4-chlorophenol, phenol and glyphosate. Into each tube containing $0.5 \mathrm{ml}$ portion of X4-strength nutrient broth, requisite volumes of distilled water and stock solutions ( 800 or $8000 \mathrm{mg} \mathrm{L}^{-1}$ ) of respective phenolic compound and glyphosate were added. Thereafter, $0.1 \mathrm{ml}$ of $0.2 \%$ aqueous solution of INT and $0.5 \mathrm{ml}$ of riverwater sample were added into each tube to obtain varying concentrations of toxicants in each quaternary mixture ratio. The final concentrations of the toxicants ranged from 0 to $3000 \mathrm{mg}$ $\mathrm{L}^{-1}$. Each concentration of the quaternary mixture and the individual toxicants were prepared in triplicates. Controls were prepared without the toxicants. Triplicate control tubes were prepared for each test toxicant, giving a total of 12 controls. The cultures were incubated at room temperature (28 $\pm 2^{\circ} \mathrm{C}$ ) for $24 \mathrm{~h}$. After incubation, $1 \mathrm{ml}$ of $1 \% \mathrm{v} / \mathrm{v}$ triton $\mathrm{X}-100$ was added into each tube, shaken for $1 \mathrm{~min}$ and allowed to stand at room temperature for $10 \mathrm{~min}$ to permeabilize the cell membrane (Lee et al., 1988). The INT-formazan (INTF) produced in each tube was then extracted in $4 \mathrm{ml}$ of butanol. 
The formazan extract was cleared by centrifugation at 3000 rpm for 10 mins. Thereafter, absorbances of the extracts were determined spectrophotometrically at $500 \mathrm{~nm}$ using butanol as blank. There was no colour interference and non enzymatic reduction of INT by the toxicants, triton X-100, and butanol. Thus, no colour correction factor was applied in the assay.

\section{Data analysis}

The inhibition of dehydrogenase activity from each toxicity assessment was transformed relative to the mean of controls (with standard deviation $<5 \%$ ) to a 0 to $100 \%$ scale as shown in Eq. 1. The normalized responses were generated as mean and their standard deviations from triplicate determinations.

$$
\mathrm{R}=\frac{C_{A}-T_{A}}{C_{A}} \times 100
$$

Where $\mathrm{R}$ is the inhibition (\%) of dehydrogenase activity, $C_{A}$ is the mean absorbance of INTF extract in the control experiments and $T_{A}$ is absorbance of INTF extract in the test experiment with different concentrations of toxicants.

The dose-response data of the individual toxicants as well as the mixtures were then graphed and fitted with 2-parameter logistic function (Eq. 2).

$$
\mathrm{R}=\frac{100}{1+\left(\frac{x}{E C_{50}}\right)^{b}}
$$

Where $x$ is the concentration of toxicant, $E C_{50}$ is the concentration of toxicant that inhibited dehydrogenase activity by $50 \%$ and $b$ is the slope at $E C_{50}$.

In order to predict stimulation of dehydrogenase activity at low doses of glyphosate or its mixtures with 2,4-DCP, 4-CP or phenol, the dose-response data were fitted to hormetic model (Eq. 3) of Schabenberger et al. (1999).

$\mathrm{R}=100-\left[\frac{100+f x}{1+\left[\frac{p}{100-p}+\left\{\left(\frac{100}{100-p}\right) \frac{f E C_{p}}{100}\right\}\right] \cdot\left(\frac{x}{E C_{p}}\right)^{b}}\right]$

Where $f$ is the parameter describing the degree of hormetic response, $p$ is the percentage decrease in the response, $E C_{p}$ is the concentration of the toxicant at a given $p$. The parameter $b$ is no longer the slope at $E C_{50}$ (Cedergreen et al., 2005).

\section{The toxic unit (TU) and toxic index (TI)}

The toxicity of each mixture component expressed in $\mathrm{TU}$ was calculated as shown in Eq. 4.

$$
\mathrm{TU}=\frac{C_{m i x}}{E C_{50}}
$$

Where $C_{m i x}$ is the concentration of the component in the mixture at the $E C_{50}$ of the mixture and $E C_{50}$ is the concentration of the component that elicited $50 \%$ decrease in dehydrogenase activity when tested as an individual.

The Toxic Index (TI) of each mixture was calculated as sum of TU for all the components of the mixture (Eq. 5).

$$
\mathrm{TI}=\sum_{i=1}^{n} \mathrm{TU}
$$

Where $n$ is the number of components in the mixture. $\mathrm{TI}=1$ describes additivity, $\mathrm{TI}>1$ describes antagonistic interaction and $\mathrm{TI}<1$ describes synergistic interaction (Boillot \& Perrodin, 2008).

\section{Prediction of mixture toxicities}

Effective concentration of the mixture $\left(E C_{x(\text { mix }}\right)$ obeying concentration addition (CA) can be predicted from the equation:

$$
E C_{x(\text { mix })}=\left(\sum_{i=1}^{n} \frac{\pi_{i}}{E C_{x i}}\right)^{-1}
$$

Where $n$ is the number of components, $\pi_{i}$ is the proportion of $i$ th component in the mixture, such that the sum of $\pi_{i}=1$, $E C_{x i}$ is the concentration of $i$ th component that gave $x$ effect when tested as an individual. In an $n$-component mixture, Eq. 6 for an $E C_{50 i}$ can be substituted into Eqs. 2 and 3 to give Eqs. 7 and 8 respectively:

$$
\begin{aligned}
& \mathrm{R}=\frac{100}{1+\left(\sum_{i=1}^{n} \frac{\pi_{i} x}{E C_{50 i}}\right)^{b}} \\
& \mathrm{R}=100-\frac{100+f x}{1+\left[1+\left(\frac{2 f}{100\left(\sum_{i=1}^{n} \frac{\pi_{i}}{E C_{50 i}}\right)}\right)\right] \cdot\left(\sum_{i=1}^{n} \frac{\pi_{i} x}{E C_{50 i}}\right)^{b}}
\end{aligned}
$$

Where $x$ is the total concentration of all the components in the mixture and $b$ is the average slope for individual components (Rider \& LeBlanc, 2005).

The CA models (Eq. 7 and 8) were used to predict the joint effect of the quaternary mixtures depending on whether there was hormesis or not (Nweke et al. 2015).

The size of hormetic response $f$ was predicted from the relative proportion of each compound in the mixture as described by Belz et al. (2008). If two compounds A and $\mathrm{B}$ are mixed with a proportion $p \%$ of $\mathrm{A}$ and $(100-p) \%$ of component $\mathrm{B}$, then the expected $f$ at $\mathrm{p}\left(f_{p}\right)$ is given by:

Thus,

$$
f_{p}=f_{A} \frac{p}{100}+f_{B} \frac{100-p}{100}
$$

$$
f_{p}=f_{A} \pi_{A}+f_{B} \pi_{B}=\sum_{i=1}^{n} f_{i} \pi_{i}
$$

Where $n$ is the number of components, $\pi_{i}$ is the proportion of $i$ th component in the mixture. Using the predicted $f$ (obtained 
by fitting the dose-response relationships of individual components into hormesis model) and average $b$, the effect of the quaternary mixture on stimulation of dehydrogenase activity was predicted on the basis of concentration addition (CA) using the hormesis model. In each case, the predicted $E C_{50}$ was compared with the experimental $E C_{50}$.

Curve fittings were implemented with TableCurve $2 \mathrm{D}$ v5.01. A 2-way Anova with replication to test for the influence of the different concentration ratios and the method of prediction on the $E C_{50} s$ was implemented with Microsoft Excel 2003. The 2-way Anova was based on the different mixtures (as factor $\mathrm{A}$ on the columns) and the method of predicting the $E C_{50}$, experimentally derived or CA-predicted (as factor B in the rows). The Duncan post-hoc tests were done using IBM SPSS Statistics 21.

\section{Model deviation ratios (MDR)}

The model deviation ratios (MDR) were calculated as the ratio between the predicted effect concentration and the experimentally observed effect concentration at $E C_{50}$. A MDR of greater than 1 indicated that the model underestimated toxicity, while a value of less than 1 indicated that the model overestimated toxicity.

$\mathrm{MDR}=\frac{\text { Predicted } E C_{50}}{\text { Experimental } E C_{50}}$

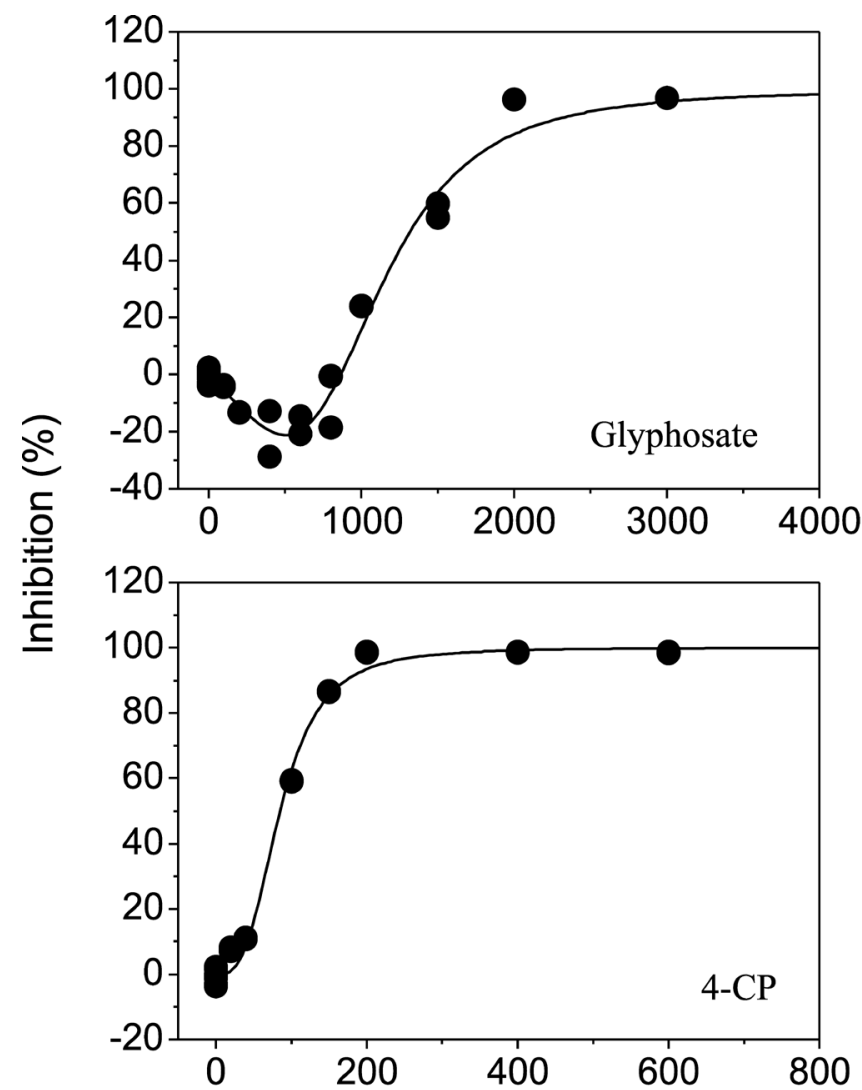

\section{RESULTS AND DISCUSSION}

The responses of the microbial community to the toxicity of glyphosate, phenol, 4-CP and 2,4-DCP as individuals are shown in Figure 1. Glyphosate had biphasic effect on the dehydrogenase activity of the microbial community. Hormesis occurred at concentrations up to $800 \mathrm{mg} \mathrm{L}^{-1}$ glyphosate. Above this hormetic concentration range, glyphosate progressively inhibited dehydrogenase activity of the community, reaching $96.92 \%$ inhibition at $3000 \mathrm{mg} \mathrm{L}^{-1}$. Similarly, phenol, 4-CP and 2,4-DCP progressively inhibited dehydrogenase activity reaching $96.68 \%, 98.82 \%$ and $99.68 \%$ at $3000 \mathrm{mg} \mathrm{L}^{-1}, 600$ $\mathrm{mg} \mathrm{L}^{-1}$ and $1500 \mathrm{mg} \mathrm{L}^{-1}$ respectively. The median inhibitory concentrations $\left(\mathrm{EC}_{50}\right)$ of the toxicants are shown in Table 2. Glyphosate with the $\mathrm{EC}_{50}$ of $1317.946 \pm 51.460 \mathrm{mg} \mathrm{L}^{-1}$ was the least toxic while 2,4-DCP with the $\mathrm{EC}_{50}$ of $60.897 \pm 5.199 \mathrm{mg}$ $\mathrm{L}^{-1}$ was the most toxic.

The toxicity of the quaternary mixtures of glyphosate, phenol, 4-CP and 2,4-DCP are shown in Figure 2. As was the case with glyphosate as individual, the 60:20:10:10 (mixture 2) and 80:10:5:5 (mixture 4) glyphosate: phenol: 4-CP: 2,4DCP mixtures exhibited hormesis at low doses up to $200 \mathrm{mg}$ $\mathrm{L}^{-1}$ and $600 \mathrm{mg} \mathrm{L}^{-1}$ respectively. Other mixtures inhibited dehydrogenase activity even at low doses. The responses of the community to the mixtures as predicted from the CA model are also shown in Figure 2. The experimentally-derived
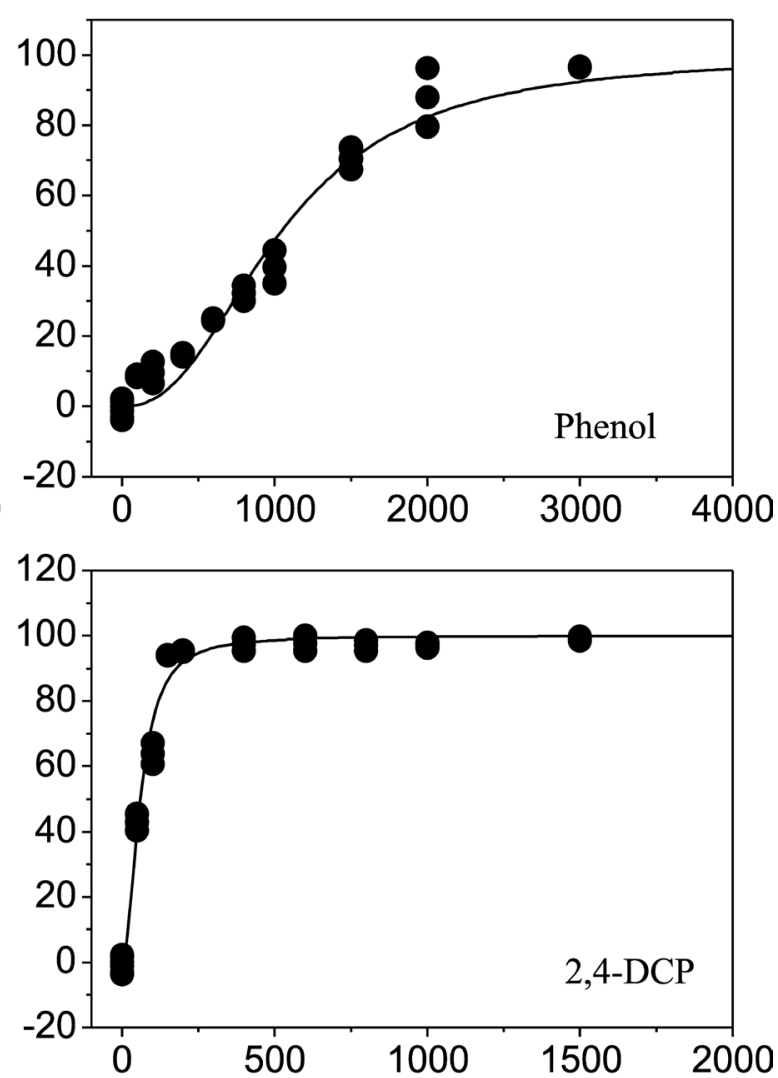

\section{Dose $\left(\mathrm{mg} \mathrm{L}^{-1}\right)$}

Figure 1- Inhibition of dehydrogenase activity in riverwater microbial community by the individual toxicants 
Table 2- The $E C_{50}$ of individual substances

\begin{tabular}{lc}
\hline Compound & $\mathrm{EC}_{50}\left(\mathrm{mgL}^{-1}\right)$ \\
\hline Glyphosate & $1317.946 \pm 51.460$ \\
Phenol & $1046.414 \pm 65.534$ \\
4-CP & $85.080 \pm 4.468$ \\
$2,4-\mathrm{DCP}$ & $60.897 \pm 5.199$ \\
\hline
\end{tabular}

$E C_{50} s$ and CA-derived $E C_{50} s$, the model deviation ratios and the toxic index for the various mixtures are shown in Table 3. The CA model predicted similar toxicity of 5:5:10:80 (mixture 3) as the experiment would suggest. Similarly, with 5:80:5:10 (mixture 5) mixture, the CA model predicted toxicities that were close to the experimentally-derived values. However, the model underestimated the toxicity of mixture 3 and overestimated the toxicity of mixture 5 at low doses (Fig. 2). In the other mixtures, CA model slightly overestimated
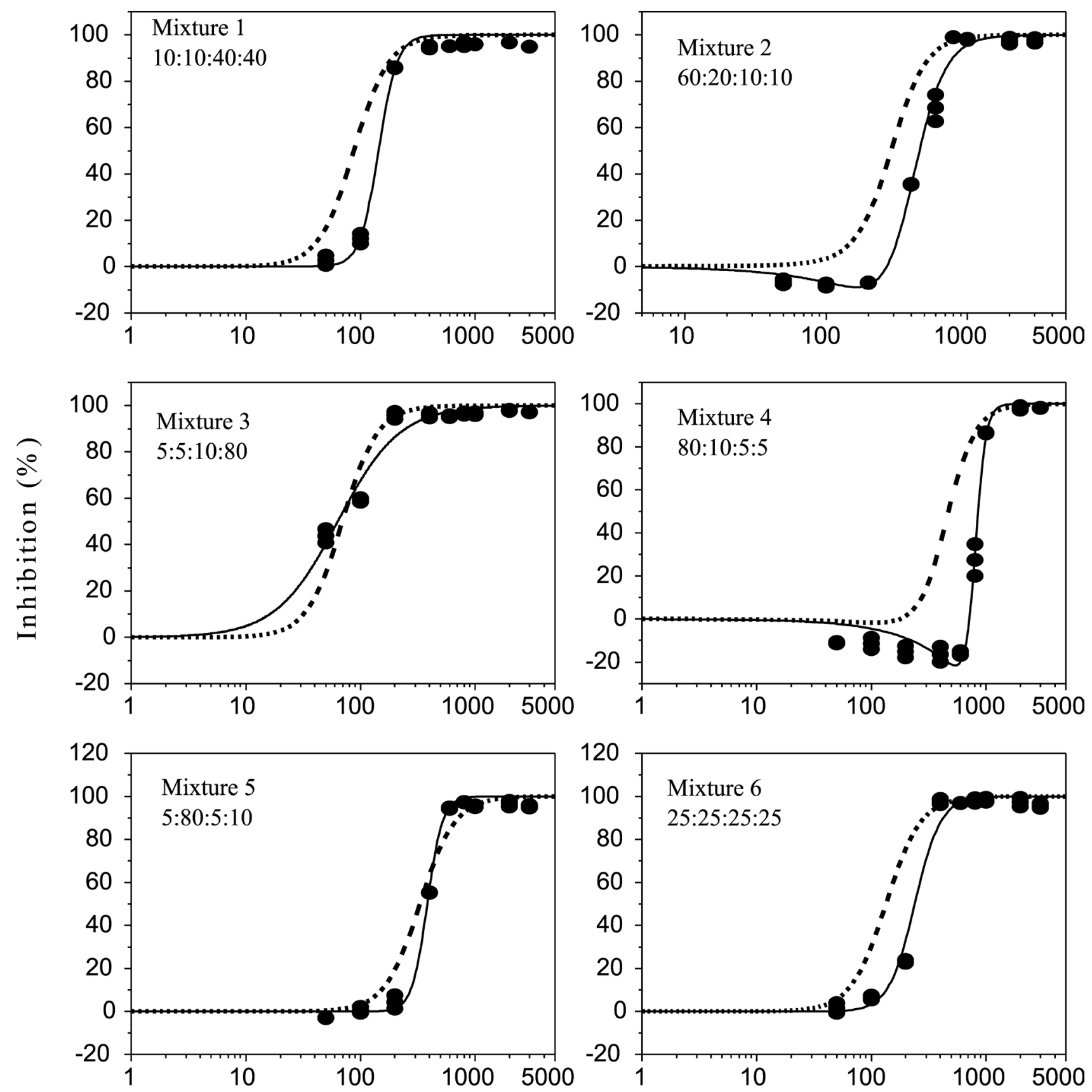

\section{Dose (mg L $\left.{ }^{-1}\right)$}

Figure 2- Experimental and predicted dose-response data for the inhibition of dehydrogenase activity in riverwater microbial community by mixtures of glyphosate and phenolic compounds (in the ratio; glyphosate: phenol: 4-CP: 2,4-DCP). Data points represent experimentally-derived values. The solid lines represent the logistic model (Eq. 2) or hormesis model (Eq. 3) fit to the experimental data and the dashed lines represent values predicted from CA models (Eq 7 (without hormesis) or Eq 8 (with hormesis)). 
Table 3 - Toxicological parameters of the quaternary mixtures of glyphosate and phenols

\begin{tabular}{lccccc}
\hline \multirow{2}{*}{ Mixture } & \multicolumn{2}{c}{$E C_{50}\left(\mathrm{mgL}^{-1}\right)$} & MDR & TI & Effect $^{* *}$ \\
\cline { 2 - 4 } & Experimental $^{\dagger}$ & Predicted & & & \\
\hline 1 & $143.781 \pm 6.868^{\mathrm{a}}$ & $87.386 \pm 6.240^{\mathrm{a}}$ & $0.607 \pm 0.014$ & $1.647 \pm 0.039$ & ANT \\
2 & $459.411 \pm 16.648^{\mathrm{b}}$ & $288.630 \pm 19.315^{\mathrm{b}}$ & $0.628 \pm 0.019$ & $1.594 \pm 0.049$ & ANT \\
3 & $63.432 \pm 6.438^{* \mathrm{c}}$ & $69.450 \pm 5.730^{*}, \mathrm{a}$ & $1.096 \pm 0.021$ & $0.912 \pm 0.017$ & ADD $^{\mathrm{a}}$ \\
4 & $855.434 \pm 16.153^{\mathrm{d}}$ & $473.516 \pm 29.322^{\mathrm{c}}$ & $0.553 \pm 0.024$ & $1.810 \pm 0.078$ & ANT \\
5 & $382.943 \pm 10.245^{\mathrm{e}}$ & $329.742 \pm 23.985^{\mathrm{d}}$ & $0.860 \pm 0.040$ & $1.164 \pm 0.054$ & ADD $^{\mathrm{b}}$ \\
6 & $239.454 \pm 12.454^{\mathrm{f}}$ & $133.803 \pm 9.444^{\mathrm{e}}$ & $0.558 \pm 0.011$ & $1.791 \pm 0.036$ & ANT \\
\hline
\end{tabular}

${ }^{\dagger}$ Within column, all experimental $E C_{50}$ values are statistically different $(\mathrm{p}<0.05)$ from each other

$\$$ Within column, predicted $E C_{50}$ values with same letters are not statistically different $(\mathrm{p}>0.05)$ from each other

*No significant difference $(\mathrm{p}>0.05)$ between experimental and predicted $E C_{50}$ for mixture 3. Other predicted $E C_{50 s}$ without asterisks are statistically different from the corresponding experimental values.

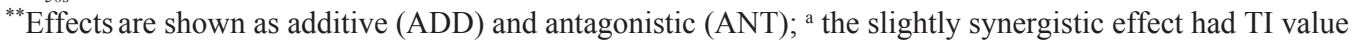
close to 1 and was taken to be additive; ${ }^{\mathrm{b}}$ the slightly antagonistic effect had TI value close to 1 and was taken to be additive

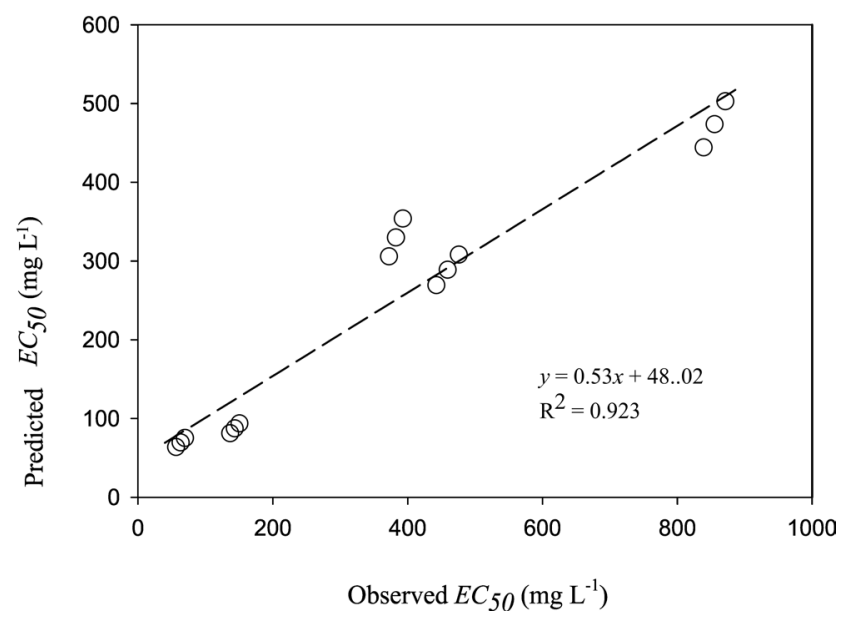

Figure 3-Correlation between the predicted and experimentally-observed $E C_{50}$ of the quaternary mixtures.

the inhibition of dehydrogenase activity. The 2-way Anova comparisons among the different concentration ratios and between the experimentally observed and CA-predicted toxicity indicated strong statistical difference between the toxicity of the different metal mixtures $(\mathrm{p}=6.4 \mathrm{E}-28)$ and that strong statistical difference existed between experimentally observed and predicted toxicities $(\mathrm{p}=1.8 \mathrm{E}-18)$. The relationship between the predicted and observed $E C_{50}$ is shown in Figure 3. The $\mathrm{R}^{2}$ value of 0.923 indicated strong positive correlation between the predicted and observed toxicity.

Hormesis is a dose-effect phenomenon that is characterized by low-dose stimulation and high-dose inhibition (Calabrese \& Baldwin, 2001). This biphasic response to chemicals occurs widely in microorganisms and higher forms of life (Calabrese \& Blain, 2005). Nweke et al. (2014) reported hormetic effects of glyphosate at low doses on the dehydrogenase activity in pure culture of Rhizobium species. Stimulation of microbial activity following glyphosate application in soil has been reported (Araujo et al., 2003; Ratcliff et al., 2006; Partoazar et al., 2011; Allegrini et al., 2015). The stimulation of dehydrogenase activity at low doses of glyphosate could be attributed to possible use of glyphosate as carbon and energy source. Several bacterial species have been demonstrated to grow on glyphosate and its biodegradation intermediate (Dick \& Quinn, 1995; Gimsing et al., 2004; Moneke et al., 2010). Thus, the observed hormesis could be due to increase in respiration response at low concentrations due to sarcosine, an intermediate of glyphosate biodegradation (Allegrini et al., 2015). In addition, it could be a stress response in glyphosate sensitive species at low concentrations due to the "energy drain" resulting from the ATP used in the accumulation of shikimate and hydroxybenzoic acids (Zabaloy et al., 2012).

The inhibition of dehydrogenase activity observed in this study at higher concentrations of glyphosate and phenols corroborated other reports. Toxicity of glyphosate to bacteria and other microorganisms have been reported (Botelho, et al., 2012; Shehata et al., 2013, Nweke et al., 2014). Glyphosate exhibits higher toxicity in soil-free media (Busse et al., 2001). The non-specific dehydrogenase activity appeared to be a less sensitive response for assessing toxicity of glyphosate to bacteria. An $\mathrm{IC}_{50}$ of $18.2 \mathrm{mg} \mathrm{L}^{-1}$ glyphosate for Vibrio fischeri bioluminescence was reported by Bonnet et al. (2007). Similarly, Tsui \& Chu (2003) reported $\mathrm{IC}_{50}$ of $162.0 \mathrm{mg} \mathrm{L}^{-1}$ and $24.9 \mathrm{mg} \mathrm{L}^{-1}$ for glyphosate (isopropylamine salt) and Roundup ${ }^{\circledR}$ respectively. Based on inhibition of non-specific dehydrogenase activity, Nweke et al. (2014) reported an $\mathrm{IC}_{50}$ of $661.614 \pm 33.234 \mathrm{mg} \mathrm{L}^{-1}$ glyphosate (in Roundup ${ }^{\circledR}$ ) against pure culture of root nodule Rhizobium species..

Phenolic compounds are known to disrupt membrane functions by causing loss of cytoplasmic membrane integrity (Heipieper et al., 1991). Dehydrogenase enzymes are membrane- associated; thus loss of membrane integrity will eventually affect their activity. The order of toxicity is 
2,4-dichlorophenol $>$ 4-chlorophenol $>$ phenol $>$ glyphosate. This trend is similar to what was obtained with pure culture of Rhizobium species (Nweke et al., 2014). However, the microbial community was more tolerant to the formulated glyphosate than Rhizobium species. A lower $\mathrm{IC}_{50}$ of 177 and $210 \mathrm{mg} \mathrm{L}^{-1}$ phenol based on inhibition of dehydrogenase activity in Pseudomonas fluorescens ATCC 13525 was reported (Abbondanzi et al., 2003). In Escherichia coli, Cenci et al. (1987) estimated median inhibitory concentration $\left(\mathrm{IC}_{50}\right)$ of phenol and 4-chlorophenol against dehydrogenase activity at $6.76 \mathrm{mM}\left(636.18 \mathrm{mg} \mathrm{L}^{-1}\right)$ and $1.6 \mathrm{mM}(205.78$ $\mathrm{mg} \mathrm{L}^{-1}$ ) respectively. More recently, $115.824 \pm 11.05 \mathrm{mg} \mathrm{L}^{-1}$ 4-chlorophenol was reported to inhibit $50 \%$ of dehydrogenase activity in Pseudomonas species isolated from petroleum refinery wastewater (Nweke \& Okpokwasili, 2010b). In a similar study, $\mathrm{IC}_{50}$ ranging from 471.419 to $1415.671 \mathrm{mg} \mathrm{L}^{-1}$ phenol against dehydrogenase activity in wastewater bacteria was reported (Nweke \& Okpokwasili, 2010a)

The good correlation between the observed and predicted toxicity might be due to the toxicants exhibiting same mode of action against the microbial community. The phenols used in this study are known to be polar narcotics (Aptula et al., 2002) and as mentioned earlier, they disrupt the functions of the cell membrane. Although, glyphosate may not have narcotic effect, the polyoxyethylene amine (POEA) used in its formulation is a surfactant and may have membranedamaging effect on microorganisms. Navarro \& Martinez (2014) reported that (POEA) can cause toxic effects in fish, which are related to an imbalance in the redox state. Thus, CA model was expected to have good prediction of the mixture toxicity. As was mentioned earlier, CA model gave good prediction of the toxicities of mixtures 3 and 5 , indicating that they are additive.

In our previous study, we reported the mutual modulation of toxicities in binary mixtures of formulated glyphosate with 2,4-dichlorophenol, 4-chlorophenol or phenol to produce synergistic and antagonistic effects. (Nweke et al., 2014; 2015). However, statistical analysis lead to the conclusion that the joint action of the mixtures on Rhizobium species dehydrogenase activity was additive. Similar observations were made in this study with microbial community of river water. The MDR and TI values indicated slight synergistic and antagonistic interactions among the components of the chemical mixtures. Nevertheless, the values are within $0.5-2.0$ range, thus the mixtures are said to be additive (Petersen \& Tollefsen, 2011; Li et al., 2014).

\section{CONCLUSION}

The in vitro toxicities of the quaternary mixtures of formulated glyphosate and phenols (2,4-DCP, 4-CP and phenol) were predicted using concentration addition (CA) and toxic index (TI) models. The models indicated possibility of synergistic and antagonistic actions. However, the MDR and TI values lie between 0.5 and 2.0. These values are within the expected inter-laboratory/inter-experiment deviation for most species.
We therefore concluded that the joint actions of the mixtures on microbial community of the river water were additive.

\section{REFERENCES}

ABBONDANZI F, CACHADA A, CAMPISI T, GUERRA R, RACCAGNI, M, \& IACONDINI, A. 2003. Optimisation of a microbial bioassay for contaminated soil monitoring: bacterial inoculum standardisation and comparison with Microtox $\AA$ assay. Chemosphere 53: 889 - 897. DOI:10.1016/S00456535(03)00717-3

ALLEGRINI M., ZABALOY, M. C., \& GOMEZ EDAN V. 2015. Ecotoxicological assessment of soil microbial community tolerance to glyphosate. Sci.Total Environ. 533: $60-68$. DOI:10.1016/j.scitotenv.2015.06.096

AONOFRIESEI, F. (2007) Abundance and activity of heterotrophic bacterial community in the water column and sediments of Tekirghiol Lake. Proc. Rom. Acad., Series B 1:3-10.

APTULA, A. O., NETZEVA, T. I., VALKOVA, I. V., CRONIN, M. T. D., SCHULTZ, T. W., KÜHNE, R. \& SCHÜÜRMANN, G. 2002. Multivariate Discrimination between Modes of Toxic Action of Phenols. Quant. Struct.-Act. Relat. 21:12 - 22.

ARAUJO, A. S. F., MONTEIRO, R.T.R. \& ABARKELI, R. B. 2003. Effect of glyphosate on the microbial activity of two Brazilian soils. Chemosphere 52: 799 - 804. DOI:10.1016/ S0045-6535(03)00266-2

BAARSCHERS, W. H., DONNELLY, J. G., HETLAND, H. S. 1988. Microbial toxicity of triclopyr and related herbicides. Environ. Toxicol. 3(2): 127 - 136.

BELZ, R. G., CEDERGREEN, N. \& SØRENSEN, H. 2008. Hormesis in mixtures - Can it be predicted? Science of the Total Environ. 404: 77 - 87. DOI:10.1016/j.scitotenv.2008.06.008.

BITTON, G., KHAFIF, T., CHATAIGNER, N., BASTIDE, J. \& COSTE, C.M. 1986. A direct INT-dehydrogenase assay (DIDHA) or assessing chemical toxicity. Tox. Assess. 1: 1-12.

BOILLOT, C. \& PERRODIN, Y. 2008. Joint-action ecotoxicity of binary mixtures of glutaraldehyde and surfactants used in hospitals: use of the toxicity index model and isobologram representation. Ecotoxicol. Environ. Saf. 71: 252 - 259 . DOI:10.1016/j.ecoenv.2007.08.010

BONNET, J. L, BONNEMOY, F., DUSSER, M. \& BOHATIER, J. 2007. Assessment of the potential toxicity of herbicides and their degradation products to non target cells using two microorganisms, the bacteria Vibrio fischeri and the ciliate Tetrahymena pyriformis. Environ. Toxicol. 22: 78 - 91 . DOI: $10.1002 /$ tox.20237

BOTELHO, R. G., FROES, C. M. \& SANTOS J. B. 2012. Toxicity of herbicides on Escherichia coli growth. Braz. J. Biol. 72: 141 146. DOI:10.1590/S1519-69842012000100016

BUSSE, M. D., RATCLIFF, A. W., SHESTAK, C. J. \& POWERS, R. F. 2001. Glyphosate toxicity and the effects of long-term vegetation control on soil microbial communities. Soil Biol. Biochem. 33: 1777 - 1789.

CALABRESE, E. J. \& BLAIN, R. 2005. The occurrence of hormetic dose responses in the toxicological literature, the hormesis database: an overview. Toxicol. Appl. Pharmacol. 202: 289 301. DOI:10.1016/j.taap.2004.06.023

CALABRESE, E. J. \& BALDWIN L. A. 2001 Hormesis: U-shaped dose responses and their centrality in toxicology. Trends in Pharmacological Sci. 22: 285 - 291. DOI: 10.1016/S01656147(00)01719-3

CARAVELLI, A., GIANNUZZI, L., \& ZARITZKY, N. 2004. Effect of chlorine on filamentous microorganisms present in activated sludge as evaluated by respirometry and INT-dehydrogenase 
activity. Wat. Res. 38: 2395 - 2405. DOI:10.1016/j. watres.2004.01.044

CEDERGREEN, N., RITZ, C. \& STREIBIG J. C. 2005 Improved empirical models describing hormesis. Environ. Toxicol. Chem. 24(12): $3166-3172$

CENCI, G., CALDINI, G., MOROZZI, G. 1987. Chlorinated phenol toxicity by bacterial and biochemical tests. Bull. Environ. Contam. Toxicol. 38, $868-875$.

DAUGHERTY, D. \& KAREL S. 1994. Degradation of 2,4-dichlorophenoxyacetic acid by Pseudomonas cepacia DBO1 (pRO101) in a dual-substrate chemostat. Appl. Environ. Microbiol. 60: 3261 - 3267.

DICK, R. E. \& QUINN J. P. 1995. Glyphosate-degrading isolates from environmental samples: occurrence and pathways of degradation. Appl. Microbiol. Biotechnol. 43: 545 -550.

FAUST, M., ALTENBURGER, R., BACKHAUS, T., BLANCK, H., BOEDEKER, W., GRAMATICA, P., HAMER, V., SCHOLZE, M., VIGHI, M., GRIMME, L. H. 2003. Joint algal toxicity of 16 dissimilarly acting chemicals is predictable by the concept of independent action. Aquat. Toxicol. 63: 43 - 63. DOI:10.1016/ S0166-445x(02)00133-9

FONSECA, A. C., SUMMERS, R. S. \& HERNANDEZ, M. T. 2001. Comparative measurements of microbial activity in drinking water biofilters. Wat. Res. 35(16): 3817 - 3824.

FUKUMORI, F. \& HAUSINGER, R. 1993. Alcaligenes eutrophus JMP134 "2,4- dichlorophenoxyacetate monooxygenase" is an $\alpha$-ketoglutarate-dependent dioxygenase. J. Bacteriol. 175: 2083 $-2086$.

GIESEY, J. P. DOBSON, S. \& SOLOMON, K. R. 2000. Ecotoxicological risk assessment for Roundup herbicide. Rev. Environ. Contam. Toxicol. 167: $35-120$.

GIMSING A. L., BORGGAARD, O. K., JACOBSEN, O. S., AAMAND, J. \& SORENSEN, J. 2004. Chemical and microbiological characteristics controlling glyphosate mineralization in Danish surface soils. Appl Soil Ecol. 27: 233 242. DOI:10.1016/j.apsoil.2004.05.007

GRIFFITHS, R. P. 1983. The importance of measuring microbial enzymatic functions while assessing and predicting lond-term anthropogenic perturbations. Mar. Pollut. Bull. 14: $162-165$.

HEIPIEPER, H. J., KEWELOH, H. \& REHM, H. J. 1991. Influence of phenols on growth and membrane permeability of free and immobilized Escherichia coli. Appl. Environ. Microbiol. 57: $1213-1217$

KIM, C-W, KOOPMAN, B. \& BITTON, G. 1994. INTDehydrogenase activity test for assessing chloride and hydrogen peroxide inhibition of filamentous pure cultures and activated sludge. Wat. Res. 28: 1117- 1121.

KOHRING, G-W., ZHANG, X., \& WIEGEL, J. 1989. Anaerobic dechlorination of 2,4-dichlorophenol in freshwater sediments in the presence of sulphate. Appl. Environ. Microbiol. 55(10): 2735 $-2737$.

LEE, C.-W., KOOPMAN, B. \& BITTON, G. 1988, Evaluation of the formazan extraction step of INT-dehydrogenase assay. Tox. Assess. 3(1): $41-54$.

LI, Y., ZHANG, B., HE, X., CHENG, W-H., XU, W., LO, Y., LIANG, R., LUO, H. \& HUANG, K. 2014. Analysis of individual and combined effects of ochratoxin A and zearalenone on HepG2 and KK-1 cells with mathematical models. Toxins 6: 1177 - 1192. DOI:10.3390/toxins6041177

LYM, R. G. 2000. Leafy spurge (Euphorbia esula) control with glyphosate plus 2,4-D. J. Range Manage. 53, 66 - 72.

MONEKE, A. N., OKPALA, G. N. \& ANYANWU, C. U. 2010. Biodegradation of glyphosate herbicide in vitro using bacterial isolates from four rice fields. Afr. J. Biotechnol. 9 (26): 4067 -
4074.

MORENO, J L., HERNÁNDEZ, T., PÉREZ, A. \& GARCÍA, C. 2002. Toxicity of cadmium to soil microbial activity: effect of sewage sludge addition to soil on the ecological dose. Appl. Soil Ecol. 21:149 - 158 .

NAVARRO, C. D. C. \& MARTINEZ, C. B. R. 2014. Effects of the surfactant polyoxyethylene amine (POEA) on genotoxic, biochemical and physiological parameters of the freshwater teleost Prochilodus lineatus. Comp. Biochem. Physiol. Part C 165: 83 - 90. http://dx.doi.org/10.1016/j.cbpc.2014.06.003

NWEKE, C. O. \& OKPOKWASILI, G. C. 2010a. Influence of exposure time on phenol toxicity to refinery wastewater bacteria. J. Environ. Chem. Ecotoxicol. 2(2): 20 - 27.

NWEKE, C. O. \& OKPOKWASILI, G. C. 2010b. Inhibition of dehydrogenase activity in petroleum refinery wastewater bacteria by phenolic compounds. Ambi-Agua 5(1): 6 - 16. DOI: 10.4136/ ambi-agua. 115

NWEKE, C. O., AHUMIBE, N. C. \& ORJI, J. C. 2014. Toxicity of binary mixtures of formulated glyphosate and phenols to Rhizobium species dehydrogenase activity. J. Microbiol. Res. 4 (4): 161 - 169. DOI: 10.5923/j.microbiology.20140404.02

NWEKE, C. O., ORJI, J. C., AHUMIBE, N. C. 2015. Prediction of phenolic compound and formulated glyphosate toxicity in binary mixtures using Rhizobium species dehydrogenase activity. $A d v$. in Life Sci. 5(2): 27 - 38. DOI: 10.5923/j.als.20150502.01

ODUM, E. P. 1985. Trends expected in stressed ecosystems. Biosci. 35: 419-422.

PARTOAZAR, M., HOODAJI, M. \& TAHMOURESPOUR, A. 2011. The effect of glyphosate application on soil microbial activities in agricultural land. Afr. J. Biotechnol. 10(83): 19419 19424. DOI: $10.5897 / A J B 11.2440$

PETERSEN, K., TOLLEFSEN, K. E. 2011. Assessing combined toxicity of estrogen receptor agonists in a primary culture of rainbow trout (Oncorhynchus mykiss) hepatocytes. Aquat. Toxicol. 101: 186-195. DOI:10.1016/j.aquatox.2010.09.018

RATCLIFF, A. W., BUSSE, M. D. \& SHESTAK, C. J. 2006. Changes in microbial community structure following herbicide (glyphosate) additions to forest soils. Appl. Soil Ecol. 34: 114 124. DOI:10.1016/j.apsoil.2006.03.002

RIDER, C. V. \&. LEBLANC, G. A. 2005. An integrated addition and interaction model for assessing toxicity of chemical mixtures. Toxicol. Sci. 87(2): 520 - 528. DOI:10.1093/toxsci/kfi247

ROSSEL, D., TARRADELLAS, J., BITTON, G. \& MOREL, J. L. 1997. Use of enzymes in ecotoxicology: a case for dehydrogenase and hydrolytic enzymes. In: Tarradellas T, Bitton G, Rossel D (eds.). Soil Ecotoxicology. 1st ed. CRC Lewis Publishers. Boca Raton, pp 179-192.

SEBIOMO, A., OGUNDERO, V. W. \& BANKOLE, S. A. 2011. Effect of four herbicides on microbial population, soil organic matter and dehydrogenase activity Afr. J. Biotechnol. 10(5): 770 - 778. DOI: $10.5897 /$ AJB10.989

SCHABENBERGER, O., THARP, B. E., KELLS, J. J. \& PENNER D. 1999. Statistical test for hormesis and effective dosages in herbicide dose-response. Agron J. 91:713 - 721.

SCHNEIDER, I. \& TOPALOVA, Y. 2009. Structural and functional changes in river microbial communities after dairy wastewater discharge. Biotechnol. Biotechnol. Equip. 23 (2): $1210-$ 1216.

SHARMA, S. D. \& SINGH, M. 2001. Surfactants increase toxicity of glyphosate and 2,4-D to Brazil Pulsey. HortScience 36(4): 726 $-728$.

SHEHATA, A. A., SCHRÖDL, W., ALDIN, A. A., HAFEZ, H. M. \& KRŪGER, M. 2013. The effect of glyphosate on potential pathogens and beneficial members of poultry microbiota in vitro. 
Curr. Microbiol. 66(4): 350 - 358. DOI: 10.1007/s00284-0120277-2.

TREVORS, J. T. 1984. Electron transport system activity in soil, sediment and pure cultures. Crit. Rev. Microbiol. 11(2): 83- 100.

TSUI, M. T. K. \& CHU, L. M. 2003. Aquatic toxicity of glyphosatebased formulations: comparison between different organisms and the effects of environmental factors. Chemosphere 52:1189 - 1197. DOI:10.1016/S0045-6535(03)00306-0

U.S. EPA. 2005. Reregistration Eligibility Decision (RED) 2,4-D; EPA 738-R-05-002; U.S. Environmental Protection Agency, Office of Prevention, Pesticides and Toxic Substances, Office of Pesticide Programs, U.S. Government Printing Office: Washington, DC.

ZABALOY, M. C., GOMEZ, E., GARLAND, J. L., BIRMELE, M. \& GOMEZ, M. A. 2012. Assessment of microbial community function and structure in soil microcosms exposed to glyphosate. Appl. Soil Ecol. 61: 333 - 339. DOI:10.1016/j. apsoil.2011.12.004

ZHANG X \& WIEGEL J, 1990. Sequential anaerobic degradation of 2,4-dichlorophenol in freshwater sediments. Appl. Environ. Microbiol. 56(4): 1119 - 1127. 